\title{
Identification of Specific Odor Components \\ in Mature Male Goat During the \\ Breeding Season
}

\author{
Hiroshi Sasada, Takeyoshi Sugryama*, \\ Kyohei Yamashita* and Junji MaSAKI \\ Department of Animal Reproduction and *Department \\ of Agricultural Chemistry, Faculty of Agriculture, \\ Tohoku University, Sendai-shi 980
}

(Received November 29, 1982)

\begin{abstract}
The present study aimed to identify a specific odor secreted by the mature male goat during the breeding season. Hairs from head and neck portions with the intensive odor were rinsed with chloroform-methanol $(2: 1, v / v)$ and washed by Folch's method. The chloroform layer (lipid fraction) was separated by cold acetone and the acetone soluble fraction was saponified. After methyl esterification of the saponified fraction, analyses with GLC, GC-MS, IR and NMR were done. Following extraction and fractionation, the odor was finally collected in the saponified fraction which contained free fatty acids. As a result of GLC analysis of the saponified fraction, over twenty peaks were obtained; distinct peaks which did not accord with standards were detected at about 4.5, 7.5, 13.5 and 23 min in retention time. Analyses of substances from these peaks with GC-MS, IR and NMR revealed the existence of 4-ethyl branched fatty acids. Biological tests on the reproductive behavior using synthetic 4-ethyloctanoic acid revealed that mature does including estrous ones were interested in the odor, suggesting that the odor of the mature male goat may have a role as a releaser pheromone.
\end{abstract}

Jpn. J. Zootech. Sci., 54 (6): 401-408, 1983

Many studies on odoriferous substances related to animal behavior have been done with insects, since Butenande et al. first identified "Bombykol" from Bombyx mori as a pheromone in 1959'). In mammals, such study has been confined to laboratory or wild animals except for the pigis).

We have been interested in the mature male goat, which secrets a specific odor during the breeding season. To clarify whether this odor acts as a sex pheromone, we have been studying its characteristics ${ }^{9}$. In this report, we describe the components of the odor which were identified as ethyl-branched fatty acids.

\section{Materials and Methods}

From eight mature male goats of Saanen and Japanese Native breeds during the breeding season (September to November), hairs were cut from head and neck portions with intensive odor, and dorsum, nates and barba portions with no or slight odor.

The hairs were rinsed with several volumes of chloroform-methanol $(2: 1, \mathrm{v} / \mathrm{v}, \mathrm{C}-$ M) by Folch's method ${ }^{4)}$ and the solvent was collected. The C-M extract was washed 
with 0.2 volumes of $0.9 \%$ aqueous $\mathrm{KCl}$ and the lower layer (the chloroform layer) was collected. Fractionation was done by adding cold acetone and the fraction soluble in acetone was saponified with ethanolic $\mathrm{KOH}$. As a result, the specific odor of all the bucks was collected in the saponified fraction including free fatty acids (Fig.1).

For analysis, the saponified fraction was methyl-esterified with 5\% anhydrous hydrogen chloride in methanol. GLC (Gass liquid chromatography, Shimazu, glass column $3 \mathrm{~mm} \times 2.1 \mathrm{~m}, 1.5 \%$ OV-17 and $15 \%$ diethylene glycol succinate, FID), GLC for separation (JGC-110T, Jeol, stainless column $6 \mathrm{~mm} \times 2 \mathrm{~m}, 20 \%$ Carbowax 20 M, CTD), GC-MS (M-52, Hitachi, glass column $2.5 \mathrm{~mm} \times 1 \mathrm{~m}, 1.5 \%$ OV-17 or $3 \% \mathrm{SE} 30$, carrier gas $\mathrm{He}$, ionized voltage $20 \mathrm{eV}$ ), IR (infra red, Jasco IRA-1), and ${ }^{1} \mathrm{H}$-and ${ }^{13} \mathrm{C}-\mathrm{NMR}$ (Jeol, JNM-FX-100, solvent $\mathrm{CDCl}_{3}$, tetramethylsilane for internal standard) were used for analysis.

Besides, a preliminary test on sexual behavior was done by using a synthetic compound. Fifteen to twenty does and two castrated bucks with non-detectable odor were used. In Observation I, a $40 \mathrm{~cm}$ long stick rolled with gauze soaked in the synthetic material or solvent was hung at $110-120 \mathrm{~cm}$ above the ground in a paddock $\left(3^{\mathrm{m}} \times 10^{\mathrm{m}}\right)$ of does. In Observation II, the one castrated buck was coated with the material and the other with solvent. These treated animals were placed by a fence of the paddock of does. In both observations, response behavior was recorded.

\section{Results}

By the extraction of hairs at head and neck portions of bucks with chloroformmethanol $(2: 1, \mathrm{v} / \mathrm{v})$ and the subsequent fractionation with cold acetone and saponification, the specific odor was collected in the saponified fraction (the fraction of free fatty acids) (Fig. 1).

GLC of the methyl-esterified fraction of free fatty acids revealed four distinct peaks, which appeared at about 4.5 (peak 3), 7.5 (peak 6), 13.4 (peak 11) and 23 (peak 16) $\mathrm{min}$ in retention time and occupied $80 \sim 90 \%$ in total (Fig. 2). These peaks were not in accord with those of standard substances (methyl esterified saturated fatty acids) in which the relative retention time of $\mathrm{C}_{16: 0}$ was calculated as 1.00 (Table 1).

No difference was observed in the gas chromatogram between Saanen and Japanese Native breeds. On the other hand, GLC on the hair extracts from dorsum, nates, and barba portions in the buck in which the odor was barely recognizable resulted in only two peaks ( 6 and 11) of the above four being slightly detected. During the non-breeding season, these peaks almost vanished. In the specimens from immature males and females of various ages, these peaks were not detected even during the breeding season.

Analyses of the peaks 3,6,11 and 16 in GC-MS showed the same pattern on mass spectra in which the standard peak appeared at $\mathrm{m} / \mathrm{z} 87$ (Fig.3). By separation with GLC, two peaks (peaks 6 and 11) were trapped and subjected to NMR analysis. In ${ }^{1} \mathrm{H}-\mathrm{NMR}$ both peaks had the same pattern (signals were detected at $\delta{ }_{\mathrm{TMS}}^{\mathrm{CDCl}}{ }^{\mathrm{C}} 0.85$, 
Identification of Male Goat Odor

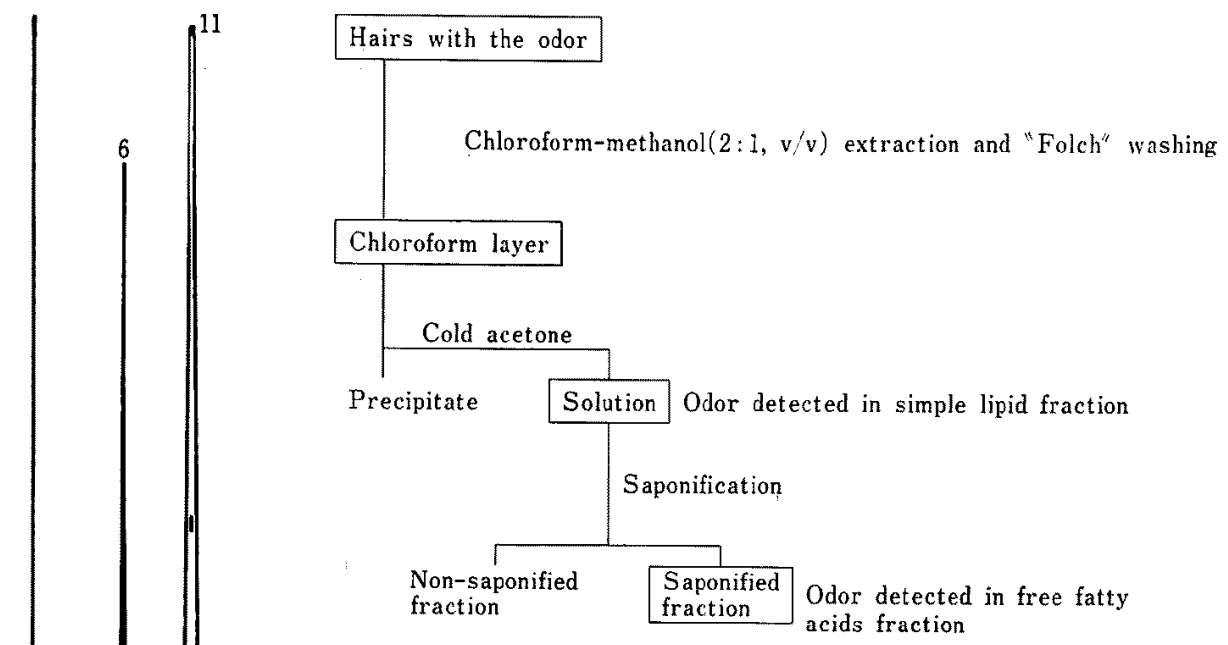

Fig. 1. Extraction and fractionation of mature male goat odor

Fig. 2. GLC chromatogram of the methyl esters of the saponified fraction in which specific odor was detected.

Table 1. Relative retention time of peaks in Fig. 1.

\begin{tabular}{cccc}
\hline \hline Peak no. & $\begin{array}{c}\text { Relative reten- } \\
\text { tion time* }\end{array}$ & Peak no. & $\begin{array}{c}\text { Relative reten- } \\
\text { tion time* }\end{array}$ \\
\hline 1 & 0.067 & 11 & 0.4 \\
2 & 0.096 & 12 & 0.484 \\
$\mathrm{C}_{8: 0}$ & 0.097 & $\mathrm{C}_{14: 0}$ & 0.524 \\
3 & 0.137 & 13 & 0.543 \\
4 & 0.151 & 14 & 0.661 \\
$\mathrm{C}_{10: 0}$ & 0.153 & 15 & 0.679 \\
5 & 0.184 & 16 & 0.739 \\
6 & 0.224 & 17 & 0.984 \\
7 & 0.270 & $\mathrm{C}_{16: 0}$ & 1 \\
$\mathrm{C}_{12: 0}$ & 0.283 & 18 & 1.098 \\
8 & 0.295 & 19 & 1.242 \\
9 & 0.317 & 20 & 1.415 \\
10 & 0.351 & & \\
\hline
\end{tabular}

*As retention time of $C_{16: 0}$ is 1.00 . 
Sasada, Sugryama, Yamashita and Masaki
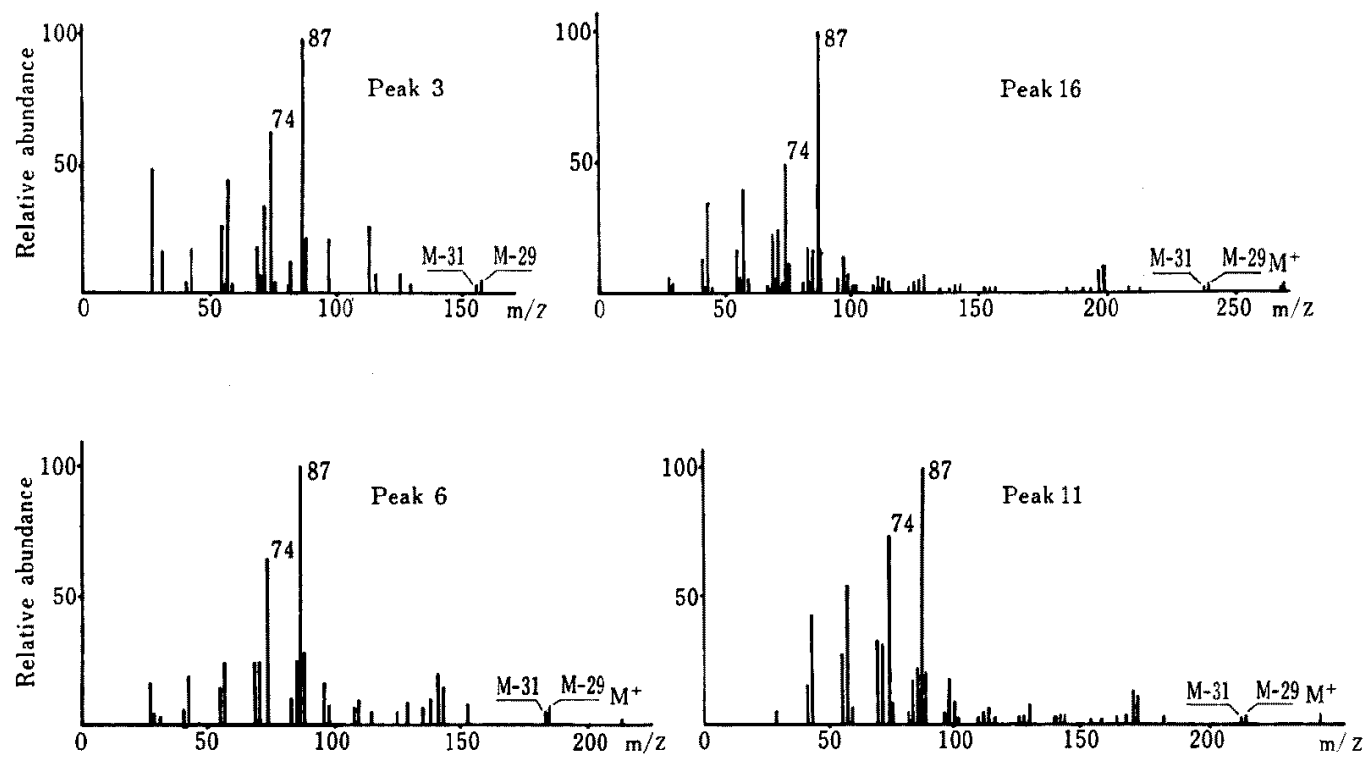

Fig. 3. Mass spectra of peaks 3, 6, 11, and 16 with GC-MS

$0.88,1.26,1.60,2.30$ and $3.66 \mathrm{ppm}$ ), but only the intensity of the signal at $1.26 \mathrm{ppm}$ was different, suggesting that both peaks contained $-\mathrm{CH}_{3},-\mathrm{CH}_{2},-{ }_{1}^{\prime} \mathrm{H}$ and $-\mathrm{OCH}_{3}$ groups (Fig. 4).

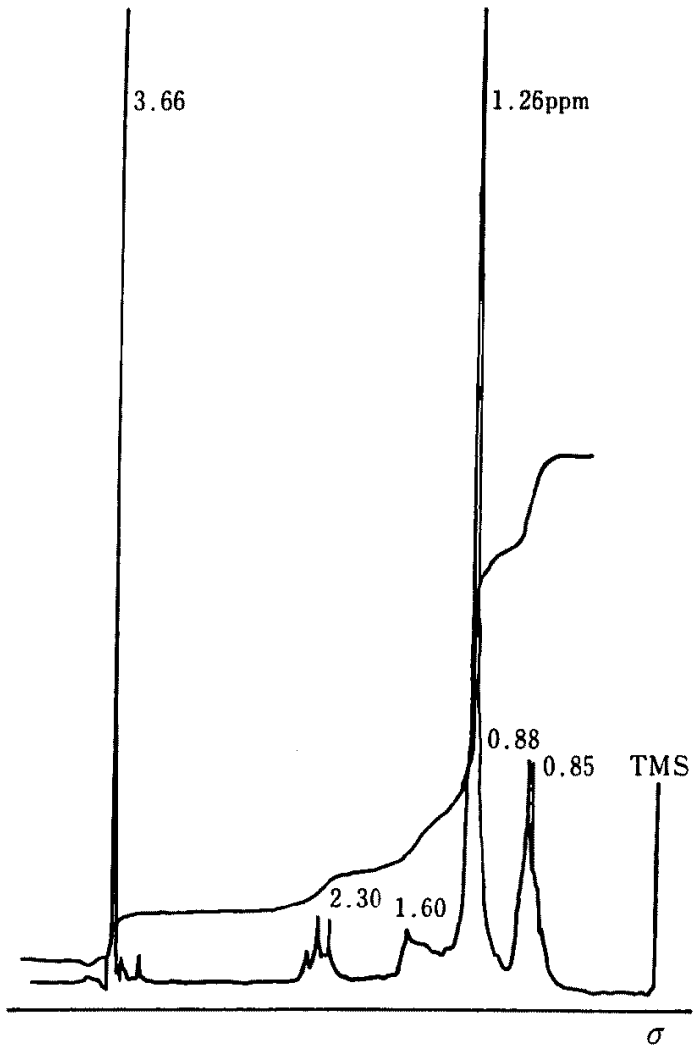

Fig. 4. ${ }^{1} \mathrm{H}-\mathrm{NMR}$ spectrum of peak 11 separated by GLC 


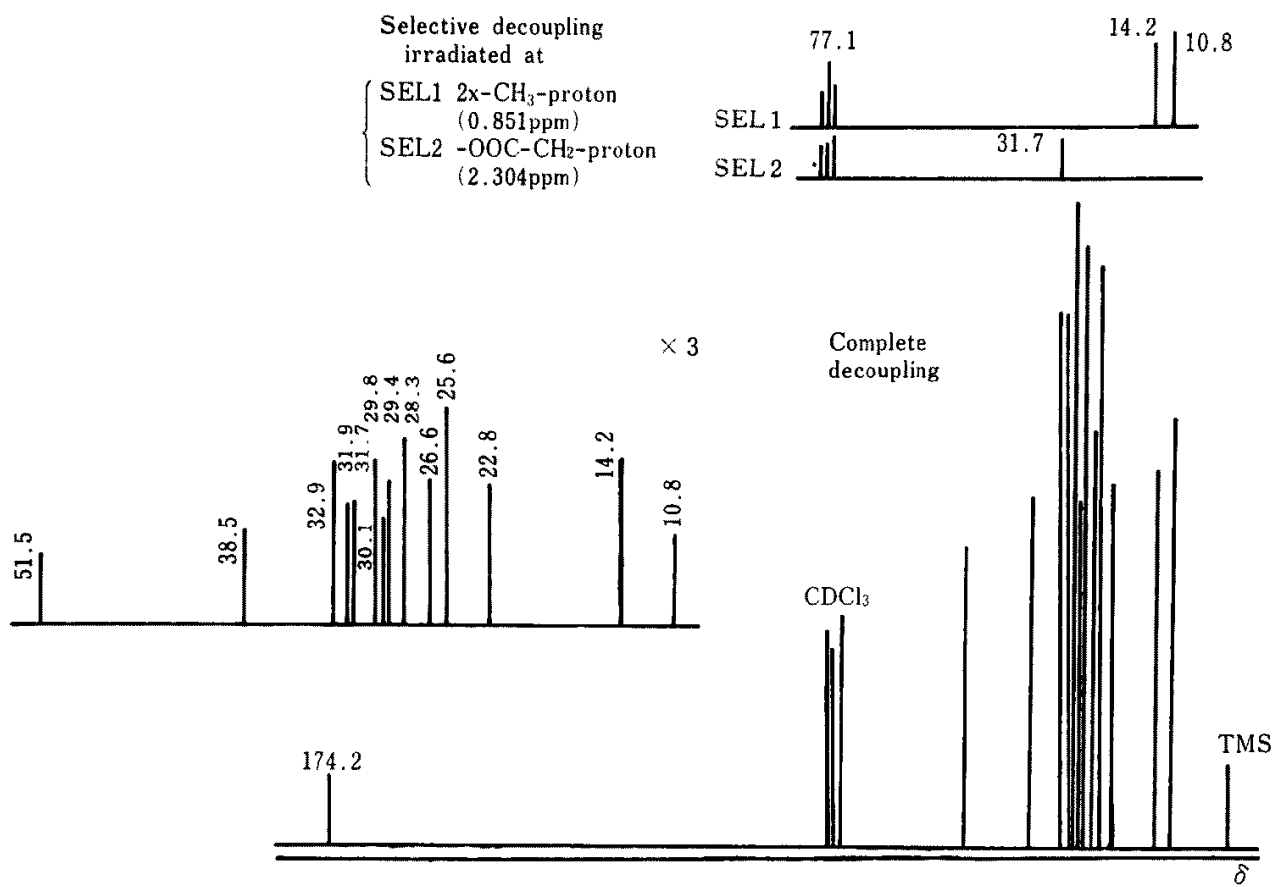

Fig. 5. ${ }^{13} \mathrm{C}-\mathrm{NMR}$ spectra of peak 11 separated by GLC

In the ${ }^{13} \mathrm{C}-\mathrm{NMR}$ analysis, the signal numbers of peaks 6 and 11 were thirteen and fifteen, respectively, and the signal pattern was very similar between them (Fig. 5). Thus, in peak 6 the signals were detected at 10.8, 14.2, 22.8, 25.6, 26.6, 28.3, $29.8,31.7,31.9,32.9,38.5,51.5$ and $174.6 \mathrm{ppm}$, while in peak 11 , at 10.8, 14.2, $22.8,25.6,26.6,28.3,29.4,29.8,30.1,31.7,31.9,32.9,38.5,51.5$ and $174.2 \mathrm{ppm}$. These figures suggested that the structures of peaks 6 and 11 contained groups of $\mathrm{C}-\mathrm{C}=0,-\mathrm{OCH}_{3},-\stackrel{1}{\mathrm{C}} \mathrm{H},-\mathrm{CH}_{3}$ and $-\mathrm{CH}_{2-}$ for the signal(s) at $174.6,51.5,38.5,14.2$ and $10.8 \mathrm{ppm}$, and the others in ${ }^{13} \mathrm{C}-\mathrm{NMR}$, respectively.

The chemical shift of $\alpha$-carbon of esters was ascertained by selective decoupling in ${ }^{13} \mathrm{C}-\mathrm{NMR}$ measurement, that is, irradiation of $\alpha$-hydrogen at $2.3 \mathrm{ppm}$ in ${ }^{1} \mathrm{H}-\mathrm{NMR}$, resulted in a observation of a signal at $31.7 \mathrm{ppm}$ as singlet. Therefore, it was considered that this signal originated from $\alpha$-carbon. Two signals originated from the group of $-\mathrm{CH}_{3}$ were detected at 14.2 and $10.8 \mathrm{ppm}$. In general ${ }^{5)}$, the terminal methyl group of fatty acid methyl esters is detected at $14 \mathrm{ppm}$. However, the signal at $10.8 \mathrm{ppm}$ was higher, suggesting that branched-chain structure existed at the third carbon numbered from this methyl group (at $10.8 \mathrm{ppm}$ ) and that the methyl group function originated from the ethyl group. Also, the chemical shift of $\alpha$-carbon detected at $31.7 \mathrm{ppm}$ was shifted higher than that of $\alpha$-carbon in saturated fatty acid esters usually detected at $34 \mathrm{ppm}$, suggesting that the branched-chain structure was at the third carbon counted from $\alpha$-carbon. Consequently, it was concluded that peaks 6 and 11 were methyl esters of 4-ethyl decanoic and 4-ethyl dodecanoic acids, respectively. This conclusion was sustained by results of analyses with GC-MS and IR. 
Peaks 3 and 16 showed the same pattern as peaks 6 and 11 in GC-MS, indicating that the formers were also the same branched-chain fatty acid methyl esters, although those peaks could not be analyzed with NMR and IR.

On the basis of this information, fatty acids with the estimated structures were synthesized ${ }^{6)}$ and the synthetic and natural substances completly accorded with respects to GLC, GC-MS, IR and NMR analyses. Thus, the components of the specific odor of the mature male goat during the breeding season were identified as 4-ethyl-branched fatty acids, i. e, 4-ethyl-octanoic, -decanoic, -dodecanoic, and-tetradecanoic acids.

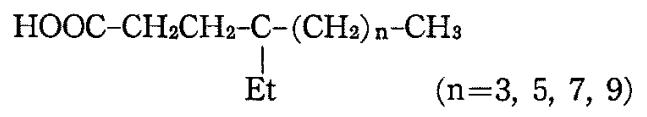

Of the components of the specific odor identified in this study, a preliminary test was done by using synthetic 4-ethyloctanoic acid, the odor of which was most like the natural ones. In Observation I, five to six does including estrous ones approached the stick of material and sniffed it, while to the stick of solvent these animals did not react. In Observation II, estrous does were interested in the castrated buck coated with the synthetic material.

\section{Discussion}

In this study, substances belonging to the branched-chain fatty acids were identified as the components of the specific odor of the mature male goat during the breeding season.

The similar fatty acids have been known to occur in tissues and fluids of several animals ${ }^{7-11}$, most of which have a methyl branch. Lipids of hairs which are thought to originate from sebaceous glands contain iso- and anteiso-methyl-branched-fatty acids $^{12}$. Accordingly, they are mainly methylbranched, whereas there are few ethyl branched ones, as detected in the preen glands of Ciconiiform birds ${ }^{13)}$. As to the latter compounds, 4-ethyloctanoic acid has been reported as one of the components of perfume ${ }^{14)}$. Although JENKINSON et al ${ }^{15)}$ have suggested that the components of the specific male goat odor are present in volatile fraction containing fatty acids of carbon number between $\mathrm{C}_{10}$ and $\mathrm{C}_{12}$, we first identified substances belonging to fatty acids.

WoNG et al. ${ }^{16)}$ have isolated the components of volatile substances in sheep meat and have identified 4-methyloctanoic acid. They have reported that this substance is also included in goat meat, so that this odor is a common odor in both sheep and goat, named "goaty odor". The specific odor demonstrated in this study was, however, extracted and isolated from hairs at portions of head to neck of all the bucks in the breeding season, and related to the development of sebaceous glands ${ }^{3)}$. This odor is specific in the mature male goat, and does not occur apparently in immature animals or the female goat (unpublished data). Therefore, the goaty odor named by WoNg et al. which occurs in goat and sheep meat seems to be different from the specific odor described in the present paper.

Effects of some odoriferous substances on the reproductive physiology have been 
reported ${ }^{17)}$. Their actions are categorized into the direct effect on reproductive behavior (releaser pheromone) and into the indirect one on endocrine status mediated by hormonal systems (primer pheromone).

In sheep ${ }^{18)}$ with agnoistic treatment, noise played a valuable role in the ram's searching behavior to the female. However, in tests using odors alone, strict response has not been obtained so far in farm animals ${ }^{18)}$, although a study on the sexual behavior in the pig using a $\mathrm{T}$ maze has demonstrated that the estrous female responds to boar odor and an organic synthesized substance, 16-unsaturated $\mathrm{C}_{19}$ steroid.

Shelton and MORrow ${ }^{19)}$ and OTT et al. ${ }^{20)}$ have recently found in the goat that existence of the mature buck stimulates the endocrine status of the doe, but the odor alone has little effect. KNIGHT and $\mathrm{LYNCH}^{21)}$ have reported that the introduction of a mature ram just before the breeding season stimulates and synchronizes ovulation in the ewe. We have observed ${ }^{3}$ that an estrous doe has an interest in a mature buck with the intensive odor, but does not after the odor is shampooed away. In a preliminary test, mature does including estrous ones were interested in a castrated buck coated with synthetic 4-ethyloctanoic acid. These findings suggest that the specific odor in the male goat identified in this study may have a role as a releaser pheromone.

The mechanism of hormonal control and the organ producing the specific odor are still uncertain. Also, the pathway of biosynthesis must be studied in future.

\section{References}

1) Shorex, H. H., Animal Communication by Pheromones. 1-17. Academic Press. New York. 1976.

2) Befuchamp, G. K., R. L. Doty, D. G. Moulton and R. A. Mugrord, in Mammalian Olfaction, Reproductive Processes, and Behavior. (Dory, R. L. ed.) 144-160. Academic Press. New York. 1976.

3) SASAda, H., The study of a specific odor of male goat. Ph. D. thesis. Tohoku University. 1981.

4) Christie, W. W., Lipid Analysis. 30-41. Pergamon Press. Oxford. 1973.

5) SuzUK1, O., Yukagaku, 25: 2-9. 1976.

6) Sugryama, T., H. Sasada, J. Masaki and K. Yamashita, Agric. Biol. Chem., 45: 2655-2658. 1981.

7) Hansen, R. P. and F. B. Shorland, Biochem. J., 50: 358-360, 1952.

8) Egge, H., U. Murawski, R. Ryhage, P. Grörgt, W. Chatranon and F. Zilliken, Chem. Phys. Lipids, 8: 42-55. 1972.

9) Gupta, A. K. S. and H. Peters, Fette Seifen Anstrich., 68: 349-360. 1966.

10) Grimmer, G. and J. Jak0B, Biochem. Z, 341: 315-324. 1965.

11) Jensen, P. G., J. G. Quin, D. L. Carpenter and J. Sampugna, J. Dairy Sci., 50: 119-126. 1967.

12) Grigor, M. R., in Lipid Metabolism in Mammals. Vol. 2. (Synyder, F. ed.) 209-235. Plenum Press. New York. 1977.

13) JACOB, J., Lipids, 13: 274-282. 1978.

14) Chem. Abstracts, 85: 1083V. 1976.

15) Jenkinson, D. M., P. S. Blackburn and R. Proudfoot, Br. vet. J., 123: 541-549. 1967.

16) Wong, E., C. B. Johnson and L. M. Nixon, N. Z. J. Agric. Res., 18: 261-266. 1975.

17) Silverman, A. K., Biblphy Reprod., 29: 89-96, 173-180. 1977.

18) Signoret, J.P., in Mammalian Olfaction, Reproductive Processes, and Behavior (DotY, R. L. ed.) 243-256. Academic Press. New York. 1976.

19) Shelton, M. and T. Morrow, Texas Agri. Exp. Sta., PR-2340: 20-21. 1965. 
20) OTt, R.S., D. R. Nelson and J.E.Hixon, Theriogenology, 13: 183-190. 1980.

21) Knight, T. W. and P. R. Lłnch, Anim. Reprod. Sci., 3: 133-136. 1980.

\title{
繁殖季節中の成熟雄ヤギ特異臭成分の同定について
}

\author{
佐々田比吕志・杉山長美 ${ }^{*}$ - 山下恭平 ${ }^{*} \cdot$ 正木淳二 \\ 東北大学農学部畜産学科, *農芸化学科, 仙台市 980
}

然殖季節中に強く出現する成熟雄ヤ代の特異臬につい て，成分の単離・同定を試みた，慗殖季節中に成熟雄ヤ

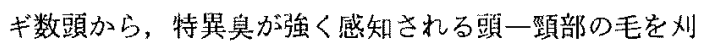

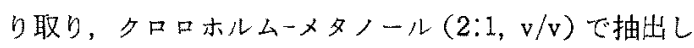
た. 続いて，クロロホルム層を冷てセトンで分画し，さ らにてセトン可溶部をケン化した。ダン化画分をメチル エステル化後, GLC, GC-MS, IR および NMR で分 析した.

特異臭收抽出・分画操作で最終的にヶン化画分に集ま ったＧLCの結果で，20以上のピークが得られたが， 顕著なピークは保持時間約 $4.5,7.5,13.5$ および 23 分
に検出された．各種の機器分析で，これらの4つのピー クは 4 位にエチル基のついた分枝脂肪酸，4ーエチルオク タン酸、4ーエチルデカン酸，4-エチルドデカン酸および 4ーエチルテトラデカン酸と同定された，有機合成を行い 比較した結果, 合成㫛と天然物は完全に一致した. 合成 品のうち，最も特買臭に近いに打い觉持った 4-エチル オクタン酸を用いた生物試験で，発情けギを含む成熟滩 ヤギが與味を示し，成熟雄ヤギの特異自がリリーサーフ ×ロモンとして作用する可能性が示陵された。

日蓄会報，54（6)：401-408，1983 